\title{
臨床研究 II
}

\section{閉塞性大腸炎の臨床的検討}

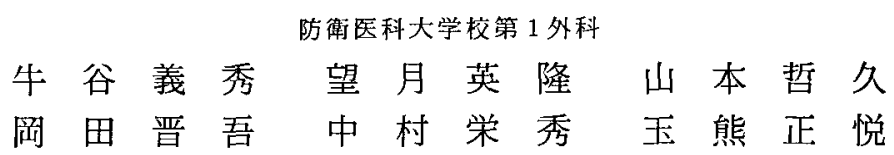

\begin{abstract}
最近13年閒に教室で経験した閉塞性大腸炎15症例に対し臨床的検討を加えた。男性10例，女性 5 例で平均

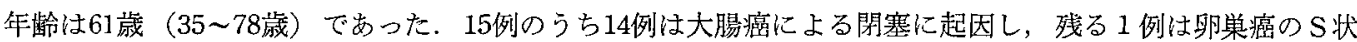
結腸浸潤による閉塞が原因であった。大腸癌による14例は同期間に教室で経験した大腸癌初回手術例 893 例の1.6\%に，また大腸癌イレウス症例の $14 \% に$ 相当し，12例までが左側結腸〜值腸の癌であった，イレウス 症状高度の 7 例と本症病变部に穿孔を伴った 4 例および医原性穿孔の計 12 例に緊急手術が施行された．切除 標本上，癌腫と口側の本症病変との閒には正常粘膜が介在し，腸間膜反対側の結腸紐に一致して線状潰瑏が 認められるものが多かった，病理学的には粘膜下の著しい浮腫と，炎症性細胞浸潤を伴うものが多く，へモ

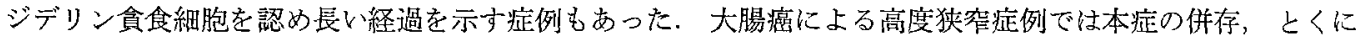
穿孔の合併に充分な注意が必要である。
\end{abstract}

索引用語 : 閉塞性大腸炎, 大腸癌, 大晹穿孔, 大腸癌イレウス

\section{はじめに}

大腸になんらかの原因で閉塞をきたした場合，その口 側にびらんや潰瘍，はなはだしい場合には穿孔をきたす ことがあり，この病態注閉塞性大腸炎 obstructive colitis として報告されている1-5). 大腸癌の発生頻度の増加 にともない，最近大腸癌に由来する閉塞性大腸炎の報告 例も増加している. 本症の原因としては大腸癌のほかに む大腸敗室症, Hirschsprung 病, 結腸吻合部狭窄, 人工 肛門狭窄，放射線障害による狭窄など，大腸の通過障害 をきたす種々の疾患があげられている゙ 経験した閉塞性大腸炎の特徵について検討を加えたので 報告する。

\section{対 象}

対象は当科開設以来1991年までの約13年間に経験した 閉塞性大腸災 15 症例で，男性 10 例，女性 5 例，平均年路 は61歳 (35 78歳) であった. 内訳は15例中14例までが 大腸癌に併発したものであり，横行結腸癌 3 例，下行結 腸癌 2 例, S 状結腸癌 6 例，直腸癌 3 例，残る 1 例《卵 宩癌のS状結腸浸潤に併発したものであった，右側横行 結晹癌の 2 症例を除き，残る13例は全て左側横行結腸か ら直腸の狭窄が原因となっていた（表 1)。これら15症
例の臨床像，標本所見，病理組織学的特徴を中心に検討 を加えた。

\section{結＼cjkstart果}

\section{A，閉塞性大腸炎の発生頻度}

教室で経験した閉塞性大腸炎は15例で，そのうち大腸 癌による14例は同期間の教室の大腸癌初回手術症例 893 例の $1.6 \%$ に相当した．とくに同期間に経験した，大腸 癌イレウス症例98例に限るとその頻度は14\%と高率であ った．残る 1 例は卵集癌のS 状結腸浸潤による閉塞が原 因であり，吻合部狭窄，人工肛門狭窄，放射線障害によ る狭窄など，癌以外の狭窄による閉塞に起因したものは 認めなかった。

B. 閉塞性大腸炎の臨床像

1. 症状拉よび病㥗期間

入院までの症状は便秘や腹部膨満感，下腹部痛，便柱 狭小化といった大腸の弨窄に上る症状，また注痹腫から の出血による下血が主症状であり，閉塞性大腸炎に特徴 的な症状といえるものは認めなかった（表 1). 症状を 自覚してから手術に至るまでの病悩期間は短いものでは 1 日，長いもので16力月におよび，一定の傾向は認めな かったが，とくに病悩期間 1 日の 2 例はいずれも突発的 で激烈な腹痛で発症した穿孔症例であった。 
表 1 閉塞性大晹炎症例の臨床像

\begin{tabular}{|c|c|c|c|c|c|c|c|c|}
\hline 症例 & 年齢。 & - 性 & 彻発症状 & 原疾患 & 肉眼型 & $\begin{array}{c}\text { 環周度 } \\
(96)\end{array}$ & 緊急または待期手術の別 & 式 \\
\hline 1 & 35 & 우 & 痛 & 下行結腸癌 & 2 & 100 & 緊急手術（バリウムイレウス） & 左結腸切除術 \\
\hline 2 & 40 & $\delta$ & 血 & $S$ 状結易癌 & 2 & 100 & 㹂急手術（イレウス） & $\mathrm{S}$ 状結腸切除術 \\
\hline 3 & 47 & 우 & 腹 満 感 & 横行結晹癌 & 2 & 50 & 㹂急手術（イレウス） & 右半結腸切除術 \\
\hline 4 & 50 & $\hat{\delta}$ & 下疬・体重減少 & $\mathrm{S}$ 状結腸癌 & 3 & 100 & 緊急手術 (イレウス) & $\begin{array}{l}\text { 高位前方切除術 } \\
\text { 十膀脱部分切除術 }\end{array}$ \\
\hline 5 & 54 & 우 & 腹 満 感 & 横行結腸癌 & 3 & 100 & 緊急手術（穿孔） & 右半結腸切除術 \\
\hline 6 & 59 & $\hat{\delta}$ & 血 & 直腸癌 $\mathrm{Rb}$ & 3 & 80 & 待期手術 & 低位前方切除術 \\
\hline 7 & 62 & $\delta$ & 腹 満 感 & 下行結腸癌 & 2 & 100 & 㹂急手術（イレウス） & 左半結腸切除術 \\
\hline 8 & 64 & $\hat{\delta}$ & 下腹部 痛 & S 状結腸癌 & 3 & 85 & 待期手術 & 左半結腸切除術 \\
\hline 9 & 67 & $\hat{\delta}$ & 下腹部痛・跳便 & 直腸癌 Ra & 2 & 100 & 待期手術 & 低位前方切除術 \\
\hline 10 & 67 & $\hat{o}$ & 痛 & 横行結腸痁 & 2 & 100 & 緊急手術（イレウス, 医原性穿孔） & 左結腸切除術 \\
\hline 11 & 67 & $\widehat{\delta}$ & 便柱狭小 & 值腸癌Rab & 3 & 100 & 㹂急手術（イレウス） & Hartmann 手術 \\
\hline 12 & 73 & 우 & 崙 & S 状結腸癌 & 2 & 60 & 緊急手術（穿 孔） & $\mathrm{S}$ 状結腸切除術 \\
\hline 13 & 75 & $\hat{\delta}$ & 下㽼・腹痛 & $\mathrm{S}$ 状結腸捳 & 2 & 60 & 緊急手術（穿孔） & Hartmann 手術 \\
\hline 14 & 78 & \$ & 秘 & S 状結腸癌 & 2 & 100 & 緊急手術（穿孔） & Hartmann 手術 \\
\hline 15 & 74 & 우 & 腹痛・腹淽感 & 卵巣 痹 & - & - & 緊急手術（イレウス） & $\begin{array}{l}\text { 左卵䉾切除術 } \\
\mathrm{S} \text { 状結腸切除紨 }\end{array}$ \\
\hline
\end{tabular}

表 2 閉塞性大腸炎症例飞枋ける術後合併症

\begin{tabular}{|c|c|c|c|c|c|}
\hline & \multicolumn{3}{|c|}{ 一期的切除吻合 } & \multicolumn{2}{|c|}{ Hartmann 手術 } \\
\hline & \multicolumn{2}{|c|}{ 緊急手術 9 例 } & \multirow{2}{*}{ 待期手術 3 例 } & \multirow{2}{*}{ イレウス 1 例 } & \multirow{2}{*}{ 穿孔 2 例 } \\
\hline & イレウス 6 例 & 穿孔 3 例 & & & \\
\hline $\begin{array}{l}\text { 創 感 染 } \\
\text { 㤦合不全 }\end{array}$ & $1(17 \%)$ & & $1(3396)$ & & $2(10096)$ \\
\hline その他 & $\begin{array}{c}1(17 \%) \\
\text { (軽度留障害) }\end{array}$ & $\begin{array}{c}1(33 \%) \\
(\text { 軽度肝障害) }\end{array}$ & & & \\
\hline 死亡 例 & 0 & 0 & 0 & 0 & 0 \\
\hline
\end{tabular}

\section{2. 併疜病態}

15例中 7 例では強度の腹部膨満と腹痛を伴ってイレウ スと診断され，また 5 例では胸部単純 $\mathrm{X}$ 線検査上 free air を認め，穿孔が確認された。これらの12例には緊急 手術が施行されており，待期手術が行われたのはわずか 3 例に過ぎなかった，穿孔 5 例のうち 4 例は閉塞性大腸 炎病変部の穿孔であり, 残る 1 例は他院での大腸ファイ バースコピーによる医原性穿孔であった．救急手術のみ ならず待期手術症例においても通過障害による腸内容の 貯溜は高度に認められた。

\section{3. 術前および術中診断}

術前症状および術前検查により大腸癌や大腸狭窄部位 の確診が得られたものは15例中 8 例であり, 残る 7 例で は病態による制約や，入院から手術に至るまでの時間的 制約から大腸癌や大腸狭窄の診断は疑診のみで，確診を 得るには至らなかった。 また術前大晹狭窄が診断されて たものでもその口側の検索は不可能であり，したがって
術前に閉塞性大腸炎の診断を得たものは皆無であった。

さらに術中の本症診断も困難なものが多かったが，本 症病変部に穿孔を合併した 4 症例と，苵窄部より $1 \mathrm{~cm}$ 口側の横行結腸から回盲弁をこえて $85 \mathrm{~cm}$ の回腸にいた るまで暗赤色の色調変化を嶈膜側から確認できた右側横 行結腸癌の 1 症例では開腹時に本症の存在が診断可能で あったしかし，他の症例はいずれも開腹所見のみで本 症の存在を確認することは不可能であり，切除標本を開 くことによりはじめて本症の合併が確認された.

\section{4. 手術術式扢よび手術成績}

教室では閉塞の高度な大腸癌手術においても一期的に 切除，再建を行ら術式を標準術式としており，それを反 映して一期的切除吻合が12例に行われ，二期的切除吻合 術が行われたものはなかった（表 1 ），術式は左結腸切 除術，左半結腸切除術，右半結腸切除術，S状結腸切除 術，前方切除術，などであった．穿孔の 2 例とイレウス の 1 例の計 3 例には Hartmann 手術が行われたが，こ 
表 3-1 閉塞性大腸炎の所見

\begin{tabular}{|c|c|c|c|c|c|c|c|c|c|}
\hline 症例 & 閉塞部 & $\begin{array}{c}\text { 大腸焱の } \\
\text { 主部位 }\end{array}$ & 切除標本シエーマ & $\begin{array}{c}\text { 閉塞部から } \\
\text { の距離cm }\end{array}$ & 病変の性状 & 数 & $\begin{array}{c}\text { 大きき } \\
(\mathrm{cm})\end{array}$ & 部 位 & 深 き \\
\hline 1 & D & D & 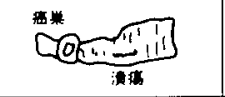 & 9.2 & $\begin{array}{c}\text { 線状潰琸 } \\
\text { ( I 条) }\end{array}$ & 単発 & $4.5 \times 0.5$ & 結晹紐上 & UI \\
\hline 2 & s & $S \sim D$ & 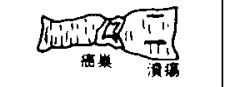 & 3.0 & $\begin{array}{c}\text { 線状潰瘍 } \\
\text { (2 桑) }\end{array}$ & 多発 & $5.0 \times 1.1$ & 間膜反対側 & UI III \\
\hline 3 & $T$ & $1 \sim A$ & 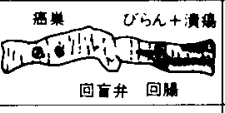 & 1.0 & 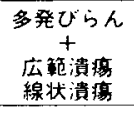 & 多発 & $26.0 \times 1.0$ & 全 周 & UI 111 \\
\hline 4 & s & $s$ & 402-11 & 1.1 & $\begin{array}{c}\text { 線状潰湯 } \\
\text { (2 条) }\end{array}$ & 多発 & $4.5 \times 0.5$ & 結腸紐上 & UI II \\
\hline 5 & $\mathrm{~T}$ & c & & 15.0 & 漬湯十穿孔 & 単発 & $4.0 \times 1.0$ & 結腸紐上 & UI IV \\
\hline 6 & $\mathrm{Rb}$ & 5 & 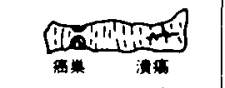 & 21.5 & $\begin{array}{c}\text { 線状漬痽 } \\
\text { ( I 条) }\end{array}$ & 单発 & $5.5 \times 0.6$ & 間 膜 側 & UI III \\
\hline 7 & D & D & 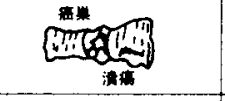 & 3.0 & $\begin{array}{c}\text { 線状謴麿 } \\
\text { (1 条) }\end{array}$ & 単発 & $2.3 \times 0.5$ & 結腸紐上 & UI I \\
\hline 8 & $s$ & $S \sim D$ & 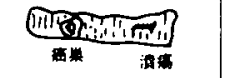 & 10.0 & $\begin{array}{c}\text { 線状㳿軎 } \\
\text { (1条) }\end{array}$ & 単発 & $6.0 \times 0.8$ & 結腸紐上 & UI 11 \\
\hline
\end{tabular}

表 3-2 閉塞性大腸炎の所見

\begin{tabular}{|c|c|c|c|c|c|c|c|c|c|}
\hline 症例 & 閉塞部 & $\begin{array}{l}\text { 大腸炎の } \\
\text { 主部位 }\end{array}$ & 切除標本シェーマ & $\begin{array}{l}\text { 閉塞部から } \\
\text { の路離cm }\end{array}$ & 病変の性状 & 数 & $\begin{array}{l}\text { 大きき } \\
\text { (cm) }\end{array}$ & 部 位 & 深 \\
\hline 9 & Ra & $S \sim R$ & 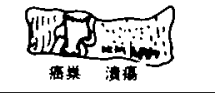 & 1.5 & 広範潰瘍 & 多発 & $8.5 \times 1.5$ & 周 & UI \\
\hline 10 & T & $T$ & (4i15) & 2.0 & $\begin{array}{l}\text { 広鉋潰瘗 } \\
(2 \text { 力所) }\end{array}$ & 多発 & $5.0 \times 4.0$ & 間膜反対側 & UI \\
\hline 11 & Rab & $R \sim S$ & 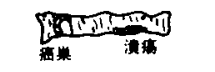 & 8.0 & 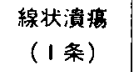 & 単発 & $5.8 \times 1.1$ & 結腸紐上 & UI \\
\hline 12 & $s$ & $s$ & 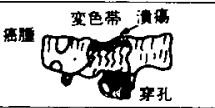 & 5.0 & 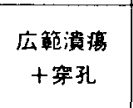 & 単発 & $8.5 \times 5.3$ & 周 & UI \\
\hline 13 & $\mathrm{~s}$ & s & 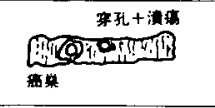 & 3.0 & 漬秥＋穿孔 & 单発 & $2.8 \times 1.0$ & 問膜反対側 & UI I \\
\hline 14 & 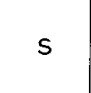 & $S \sim D$ & 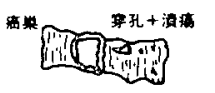 & 3.0 & 漬病＋穿孔 & 多発 & $1.5 \times 1.0$ & 結腸紐上 & UI I \\
\hline 15 & 率紧癌 & D & 究色需 & 1.0 & 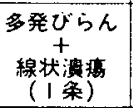 & 多発 & $7.5 \times 5.0$ & 全 & UI \\
\hline
\end{tabular}

の Hartmann 手術が行われた症例中，2例の穿孔例に は術後創感染を認めた，一方，一期的切除吻合術症例で はイレウス症例 6 例中 1 例に創感染を，待期手術 3 例中
1 例に縫合不全を認めたがいずれも保存的治療にて軽快 し，重䉆な合併は認めず，Hartmann 手術の術後成績と 比較して遜色ない結果であった（表 2). 


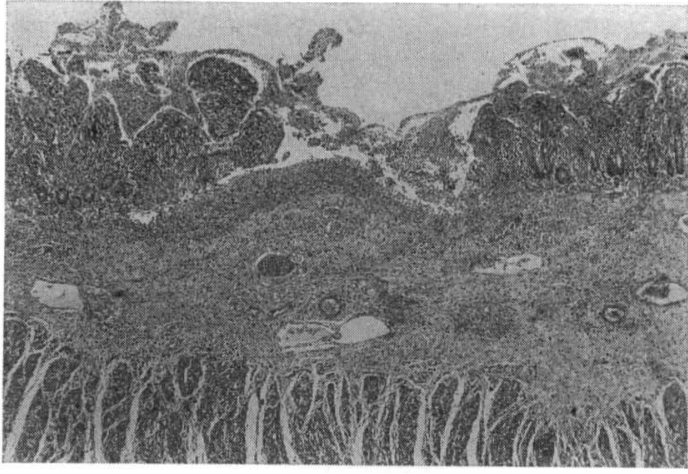

図 1 閉塞性大腸炎の病理組織像 粘膜下層にいたる浅い潰瘍をともなっており， 粘膜下層には充血, 浮腫および出血, 炎症性細 胞浸潤がみられる $(\mathrm{HE}$ 染色 $\times 4)$

\section{C. 臨床病理学的特徴}

閉塞性大腸炎を伴った大腸癌症例における癌腫の肉眼 型はすべて 2 型あるいは 3 型であり, また環周度は全周 性のもの 9 例, 亜全周性のもの 2 例と環周度の高度のも のが多かったが，3/5周以下のものも 3 例に認められ， 必ずしも全周性のものに限らなかった（表 1 ). その他 の臨床病理学的所見を表 3-1, 2 にまとめて示すが, 狭 窄の原因である癌腫と口側にみられるびらん・潰瘍性病 変との閒には連続性が見られず，いずれの症例において も両者間に1.0 21.5cm におよぶ正常粘膜の介在が み られた. 潰瘍性病変の特徵として腸間膜反対側を中心に $1 \sim 2$ 条の線状潰瘍が結腸紐に一致して縦走してみられ たものが多く, 結腸紐付着部での粘膜血流の低下を示唆 するものであった ${ }^{7)}$. 潰瘍の深さは U1 I 〜 IVまで様々 であったが, U1 IIのものが多かった. 病理組織像とし ては粘膜下の著しい浮腫と好中球やリンパ球を中心とし た炎症性細胞の浸潤や線維化を伴うものが多かった（図 1)。慢性化した状態では線維化が進行し，現在では閉 塞性大腸炎と本質的に同じ疾患で肉眼的・組織学的所見 も同一とされる虚血性大腸炎において, 以前に Marst$\mathrm{on}^{8)}$ が指摘した， ベルリン青で染色されるへモジデリン を食食したマクロファージの出現がみられた。

\section{考察}

閉塞性大腸炎の原因疾患としては狭窄を伴う大腸癌が 圧倒的に多いとされる. 本症の発生頻度はこれまでの報 告では全大腸癌症例の $0.3 \sim 2.1 \%^{3,9-11)}$ と約 $1 \%$ 程度 の 報告が多く，自験15例でも同期間に経験した大腸癌初回 手術例の $1.6 \%$ に相当した. 一方本邦での大腸癌のイレ ウス合併頻度は $8.6 \%{ }^{12)} \sim 22.7 \%{ }^{13)}$, 平均で $10 \%$ 前後と されるため，閉塞性大腸炎はイレウス大腸癌の $10 \%$ 内外

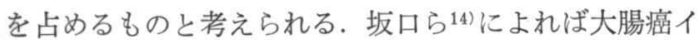

レウス症例における本症の合併頻度は $7 \%$ ぼである が，自験例では $14 \%$ とそれより高率であった. いずれに せよ，大腸癌イレウス症例における本症の発生率が $10 \%$ 内外という頻度はそれほど高率ではなく，これは本症の 発生に閉塞機転のほかにも種々の因子が複雑に関与して いる可能性を示唆するものである.

発症に関連する因子としてはこれまでに多くの検討結 果が報告されているが，大きくは11)内圧上昇による粘膜 血流障害15-17)，(2)腸管壁平滑筋痙攣性収縮18,19) (3)腸管 内細菌増殖 ${ }^{2}$ の三つに分けられる。 このうち閉塞による 腸管内圧上昇の結果生ずる粘膜血流障害の関与は, 多く の臨床家が報告している．剖検例で得られた小腸標本を 用いた Noer ら ${ }^{15)}$ の検討, Glotzer ${ }^{16)}$ や Denker ら ${ }^{17)} の$ イヌを用いた検討などは，腸管内圧上昇に伴う腸管の血 流減少を大きな要因と指摘している. 一般にわずか 10 $\mathrm{mmHg}$ 程度の腸管内圧上昇によっても粘膜の血流は大 きな影響を受けるとされている．また Lium ら ${ }^{18)}$ は， イヌの結腸筋層に痤攣性収縮を起こすことによっで結腸 粘膜に出血や潰瘍を発生しうることを示しており, 結腸 壁平滑筋の㾏攣性收縮も本症の発生には関与しているも のと推測される. 本邦でも岡島ら ${ }^{19)}$ は, 閉塞部口側腸管 の虚血には腸管内圧上昇が関与するのみならず，腸管壁 攣縮もさらにその虚血状態を進展悪化させる機序を指摘 し, 複数の因子が本症の発生に影響していることを示し ている. 一方，腸管内細菌叢の関与も重要な因子と考え られる. Hurwitzら ${ }^{2)}$ は潰瘍性病変を合併した腸管閉塞 の不完全な症例を報告し, この際の潰瘍性病変の合併原 因として腸内容の停滞による細菌増殖の機序を指摘して いる.

当科で経験した症例中にも $3 / 5$ 周以下の症例 が 3 例 み られ，閉塞性大腸炎の発症には純粋に大腸内腔の完全閉 塞という単一の因子のみが原因として関与するのではな く,これらの全ての因子が関連し合いながら複雑に影響 を及ぼしているものと考えられる. すなわち，I）大腸 癌をはじめとする完全あるいは不完全閉塞が腸管内容を 停滞させる結果, 腸内細菌が増殖すること， II）細菌増 殖によって生じた炎症性変化が, 内圧上昇の結果生じた 循環障害を更に助長して虚血状態をきたすこと，III）ま た腸管内圧の上昇に結腸壁平滑笳の㾏攣性収縮が加わる ことによって口側腸管の虚血状態を増悪すること，など の機序で潰瘍性病変が形成され，はなはだしい場合には 潰瘍性病変部の穿孔をも合併すると考えられる.

閉塞性大腸炎には特異的な症状は同定されず，腹部膨 満感や便秘などといった腸管狭窄症状や，原疾患の癌腫 からの出血などが主な症状であった．また本症は元来が 大腸の閉塞・狭窄に起因するため術前に口側腸管を十分 
表 4 穿孔をきたした閉篓性大腸炎の報告例

\begin{tabular}{|c|c|c|c|c|c|}
\hline 報 告 者 & & \multicolumn{2}{|c|}{ 年壯・性 } & 原䓡患 & 閉塞性大腸炎の所見 \\
\hline Hurwitz, et al. & $(1960)$ & \multicolumn{2}{|c|}{$?$} & 結 晹 痹 & perforations proximal to the carcinoma \\
\hline$"$ & & \multicolumn{2}{|c|}{ ? } & 結 腸 癌 & perforations proximal to the carcinoma \\
\hline Herrmann, et al. & $(1965)$ & & $\hat{\delta}$ & $S$ 状結腸癌 & $\mathrm{S}$ 状結腸 \\
\hline Tietjen, et al. & $(1975)$ & & 우 & 直腸 癌 & わずかの正常粘膜を介して，8cm亿わたる塄死性腸炎 \\
\hline Harada, et al. & $(1975)$ & 73 & 우 & $\mathrm{S}$ 状結腸癌 & $7 \mathrm{~cm} \square$ 側に，25 cmに及ふ多発漬場 \\
\hline 瀨藤, 他 & $(1978)$ & 64 & $\delta$ & $\mathrm{S}$ 状結腸癌 & $6 \mathrm{~cm}$ 口側に，4cmの単発・円形潰啺 \\
\hline 関，他 & $(1980)$ & 74 & $\hat{\delta}$ & $\mathrm{S}$ 状結晹癌 & $11 \mathrm{~cm}$ 口側に, $4 \mathrm{~cm}$ の単発・縦走潰痬 \\
\hline 高橋，他 & (1981) & 64 & $\hat{\delta}$ & $\mathrm{S}$ 状結腸癌 & 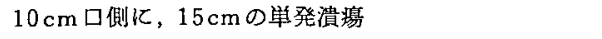 \\
\hline 山本, 他 & (1982) & 54 & 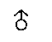 & $\mathrm{S}$ 状結腸癌 & $10 \mathrm{~cm}$ 口側に, 単発潰湯 \\
\hline 平池, 他 & $(1984)$ & 73 & $\delta$ & 人工肛門㹨窄 & 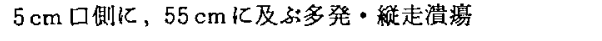 \\
\hline 荒木，他 & $(1987)$ & 78 & 우 & S 状結腸癌 & 下行結晹に穿孔 \\
\hline 安藤, 他 & (1989) & 58 & 우 & 上行結腸癌 & 盲腸に偽膜性腸炎を伴う穿孔 \\
\hline 坂口, 他 & $(1989)$ & 69 & $\hat{\delta}$ & $\mathrm{S}$ 状結腸癌 & $2 \mathrm{~cm}$ 口側 $k, 1 \mathrm{~cm}$ の不整型洗痬 \\
\hline$"$ & & 78 & 우 & $\mathrm{S}$ 状結腸癌 & $2 \mathrm{~cm}$ 口側 \\
\hline 丸尾, 他 & (1989) & 76 & $\hat{\delta}$ & $\mathrm{S}$ 状結腸癌 & $5 \mathrm{~cm}$ 口㑡に，広範謴瘍（4 力所穿孔） \\
\hline
\end{tabular}

に検査することが難しく; 本症の存在を術前に診断する ことは困難であった．さらに術中の漿膜側からの観察で も，粘膜病変を主体とする本症の存在を知ることは難し いことが多く，本症の合併を見過ごしてしまう危険が少 なくない．

教室ではイレウスを伴った大腸癌に対しても一期的切 除吻合を標準術式として行い，二期的手術と比較して術 後合併症の面で遜色ない成績をむげているが20)，閉塞性 大腸炎症例に対しても一期的手術を主として行い同様の 良好な成績を得ている. しかし潰瘍性病変の取り残しに は充分に留意すべきと考える．本症の罹患部位を取り残 して消化管吻合を行っても術後化合併症を発生したもの はないとする報告4もあるが，閉塞部位の切除後にも本 症が増悪した例 ${ }^{211}$ や，大腸澏イレウスに対して第一期手 術として減圧用人工肛門を造設した後10週経過したとこ ろで行った二期手術での切除標本にも潰瘍性病変が残存 していたとの報告もある14)。したがって高度の大腸狭窄 をきたした大腸癌症例では本症の併存を常に念頭にお き，手術中の丹念な口側腸管の検索と切除標本の術中検 討が必須であると考えている．本症を合併した場合には 吻合部の縫合不全や狭窄の合併を予防するために，潰瘍 性病変を含めた十分な腸切除を行うべく慎重な切除範囲 の決定が重要と考えられる。

表 4 汇今回検索し得た現在までの閉塞性大腸炎穿孔例 を示したが，自験の4例を加えても本邦では15例とそれ ほど多くはない，乙かし大腸癌の増加とともに閉塞性大 腸炎症例も增加することが予想され，それに伴って今後 穿孔症例に遭遇する機会も多くなるものと考えている． 腹部膨満感や便秘などといった大腸の狭窄が示唆される 症状が相当期間持続した後に突発的な激しい腹痛が出現

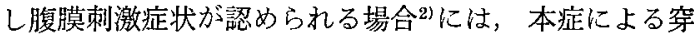
孔の合併を先ず考慮すべきである. 自験例では穿孔の 4 例以外に，穿孔に至らないまでも閉塞性大腸炎䍜患部位 の㢡膜が結腸紐に沿って腸管長軸方向に裂けていた症例 も散見されており，本症の穿孔合併は決して轻視できな い頻度で生じ得るものと考えられた。

本文の主旨注第46回日本大腸肛門病学会総会で発表し た。

\section{文献}

1) Kremen $\mathrm{AJ}$ : Acute colonic obstruction secondary to carcinoma of the sigmoid colon with gangrene of an extensive segment of the large bowel. Surgery $18: 335-338,1945$

2) Hurwitz A, Khafif RA: Acute necrotizing colitis proximal to obstructing neoplasms of the colon. Surg Gynecol Obstet 111 : 749752,1960

3) Glotzer DJ, Roth SI, Welch CE: Colonic ulceration proximal to obstructing carcinoma. Surgery $56: 950-956,1964$

4）石原明徳, 山際裕史, 浜崎豊ほか：大晹癌の 口側に合㴊する潰陽性病変。胃々晹 $10: 385$ 389, 1975

5）柴田清人，宇佐見詞津夫，加藤文彦ほ加：Obstructive Colitis について一症例ならびに成因 代っいての考察. 外科祅療 $34: 569-573,1976$

6) Boley SJ, Schwartz SS: Colitis complicating carcinoma of the colon. Vascular disorders of the intestine. ed. by Boley SJ 631642, Appleton-Century-Crofts, New York, 1971

7）野村幸治，藤田潔，針間 岙ほか：虚血性大 
腸炎の成因に関する実験的検討一大腸粘膜孟流 測定による検討. Gastroenterol. Endosc 25 : $531-536,1983$

8) Marston A: Ischemic colitis. Gut $7: 1$ 10, 1966

9) Rutledge RH: Pseudo-ulcerative colitis proximal to obstructing colon carcinoma. Am Surg $35: 384-388,1969$

10）武藤徹一郎：炎症性大腸疾患のスペクトル。 125-127, 医学書院, 東京, 1986

11）谷口交章：閉塞性大腸炎の臨床的研究. 東女医 大誌 $51: 1933-1938,1981$

12）奥野匡宥，池原照幸，阪本一次ほか：大腸癌イ レウス症例の臨床病理学的検討. 日消外会誌 $19: 957-962,1986$

13）宇都宮利善，諸角強英，村上 勝ほか：腸閉塞 症状を呈する大腸癌（その臨床的特性につい て). 日本大腸肛門病会誌 $31: 7-12,1978$

14) 圾口敏夫, 小西文雄, 腰塚史朗ほか：閉塞性大 腸炎症例 $の$ 臨床的検討. 日本大腸肛門病会誌 42 : 1153-1157, 1989
15) Noer RJ, Derr JW : Effect of distension on intestinal revascularization. Arch Surg 59 : 542-549, 1949

16) Glotzer DJ, Pihl BG: Experimental obstructive colitis. Arch Surg 92:1-8, 1966

17) Denker $H$, Lingardh $G$, Muth $T$ : Massive gangrene of the colon secondary to carcinoma of the rectum: Case report. Acta Chir Scand $135:$ 357-361, 1969

18) Lium R: Etiology of ulcerative colitis: II. Effect of induced muscular spasm on colonic explants in dogs, with comment on relation of muscular spasm to ulcerative colitis. Arch Int Med 63:210-225, 1939

19）岡島邦雄, 榎本正満：虚血性大腸炎. 外科診療 $20: 661-668,1978$

20）望月英隆，長谷和生，市倉 隆ほか：高龄者の イレウス.臨休消化器内科 $4: 1161-1169,1989$

21）加秋宣康，多羅尾信，三島 修ほか：閉塞部位 を切除後も増悪した閉塞性大腸炎の 1 例. 消外 $10: 2033-2036,1987$

\title{
A Clinical Review of 15 Patients with the Obstructive Colitis
}

\author{
Y. Ushitani, H. Mochizuki, T. Yamamoto, S. Okada, \\ E. Nakamura and S. Tamakuma \\ Fist Department of Surgery, National Defense \\ Medical College, Saitama
}

During these 13 years, 15 patients with obstructing colorectal lesion were revealed to have obstructive colitis. All of them but two had obstructing lesions on left side colon, and 14 were due to colorectal cancers. Out of 15 patients, 4 developed perforation in the colitis lesion.

In most specimens longitudinal ulcers were observed in the colitis lesion. Every specimen also showed normal mucosal area between obstructing lesion and colitis lesion.

Since obstructive colitis can develope perforation at a considerable rate, rapid surgical treatment should be considered to avoid such severe complication when a patient is revealed to have severe obstructing colorectal cancer. 